\title{
A Proposed New Product Development Process for Floor Coverings and Assessment of Its Applicability
}

\author{
Nihal Arıŏlu ${ }^{1}$, Mahmure Övül Arığlu Akan², Asiye Çolakoğlu Cengiz ${ }^{1}$ and Mete Hakan Duman ${ }^{1}$ \\ 1. Department of Architecture, Istanbul Technical University, Taskisla Campus, Istanbul 34743, Turkey \\ 2. Department of Industrial Engineering, Marmara University, Goztepe Campus, Istanbul 34722, Turkey
}

\begin{abstract}
Nowadays, the rapid changes in the marketing environment of construction products accelerate the shortening tendency of product life cycles which in return put pressure on companies to produce successful new products and adopt innovative strategies to survive and expand in the fast competitive environment. The success of the new construction products calls for a high-quality and well-managed product development process. Thus, this study aims at defining the basic steps of a NPD (new product development) process designed for floor coverings and evaluating its applicability. To this end, the product development methods of the leading companies in the construction sector in Turkey have been analyzed. Also, a questionnaire has been conducted to determine which of the steps of the proposed methodology are currently being realized and which are not or cannot be implemented. Finally, based on this information, certain suggestions have been made as to what can be done to enhance the NPD processes of the companies' subject to evaluation.
\end{abstract}

Key words: New product development, floor coverings, Turkish companies.

\section{Introduction}

In order to survive the global competitive market conditions of the 21 st century with rapidly changing consumer demands, accelerating technological advances and ultimately shortened product life-cycles, companies are urged to introduce high-quality products with reduced prices fast and effectively [1-5]. This can only be achieved by being innovation-oriented [6] at all levels and across all functions in a company [5], especially while designing and introducing new products to the market [4]. Consequently, companies started placing emphasis on NPD (new product development) to increase their profitability and gain competitive advantage in the current business environment $[2,4,7,8]$.

Innovation may be realized on the basis of new

Corresponding author: Mahmure Övül Arıŏlu Akan, Ph.D., research fields: sustainable supplier selection and evaluation, sustainable supply chain management, corporate sustainability management, social sustainability, sustainable housing, renewable energy policies, agent-based service and performance management and multivariate statistical quality control. E-mail: ovul.akan@gmail.com. product family development, adding one or more products to the existing product line, changing some of the features of the existing product or adding new features or developing a completely new product or production technology. Hence, NPD can be defined as "the transformation of a market opportunity and a set of assumptions about a product technology into a product available for sale with cross-functional integration and quick development cycles" [9].

A variety of new products are being introduced to the market as a result of the new findings, technologies and demands in the field of construction materials as well, which are rapidly growing in parallel to the changes in the construction industry and the social structure. However, while some of the new products succeed in the market, many others fail despite all efforts. Majority of these failures are attributable to a problem in the product development process.

There are various factors affecting the success of NPD, some of which can be listed as cross-functional work, top-management support, market planning, formalized processes, internal and external 
communication, inter-firm relationships and knowledge transfer $[10,11]$. Another significant issue that is still in its infancy in the current literature is the integration of sustainability in NPD. Sustainability is the most critical concept in almost every aspect of today's business environment. It has not only become a legislative obligation but is also demanded by customers and business partners. Thus, if companies want to stay competitive in the market, they should invest in sustainable and innovation-oriented new products [3, 9, 11, 12]. As much as these issues gain companies' competitive advantage, they also complicate the inherently complex NPD process due to its multi-functional and multi-stakeholder nature [3, 9-11]. The other critical concepts that have been attracting researchers, which also may provide solutions to the above-stated complexities, are risk management $[13,14]$, value analysis [5], and collaboration (i.e., the integration of customers and suppliers as business partners in NPD) $[2,4,6,8]$.

Hence, the success of the new construction products calls for a high-quality and well-managed product development process that takes the above-mentioned issues into account. A systematic NPD process not only enables the effective and efficient management of the respective projects but also prevents waste of resources, efforts and time, ultimately resulting in the successful market introduction of high-quality products in shorter periods. Consequently, it is important that the NPD processes of especially SMEs (small medium enterprises) are carried out in a methodological perspective and new processes are introduced following careful analysis.

Henceforth, an NPD process for floor coverings has been proposed, and its applicability has been evaluated by analyzing the product development methods of the leading companies in the construction sector in Turkey. To this end, Section 2 of the study introduces the proposed NPD process. Then, Section 3 describes the methodology of the study, i.e., the questionnaire conducted to determine which of the steps of the proposed process are currently being realized and which are not or cannot be implemented, while also giving a brief summary of the NPD processes of these companies. Finally, the results of the study are elaborated and suggestions are made in the last section.

\section{Proposed NPD Process for Floor Coverings}

The NPD process consists of the activities during the development of the new products and their introduction to the market. A new product undergoes a number of stages initiated with the generation of new ideas and concepts, followed by design and tests and finalized with commercialization [15]. Some of these activities are conducted for information retrieval and evaluation. The NPD process may vary from sector to sector, company to company and even in two different projects of the same company. Thus, NPD process can be interpreted as a road map guiding new product efforts, one that lays out the sequence of the involved activities [16].

There are various approaches to NPD planning and management in the literature. For instance, Perreault and McCarthy [17] include idea generation, pre-selection, idea evaluation, product development and introduction to the market steps in their methodology, while Etzel et al. [18] add the traditional market testing before market introduction to these steps. Kotler and Armstrong [19] have designed the same process to include the following eight steps: new idea generation, pre-selection, concept development and testing, establishment of the marketing strategy, commercial analysis, market testing and introduction to the market.

The NPD process proposed in this study (Fig. 1) has been developed based on the general methodology for floor coverings. The key departments in this process are management, marketing, engineering/design, manufacturing, quality assurance, 


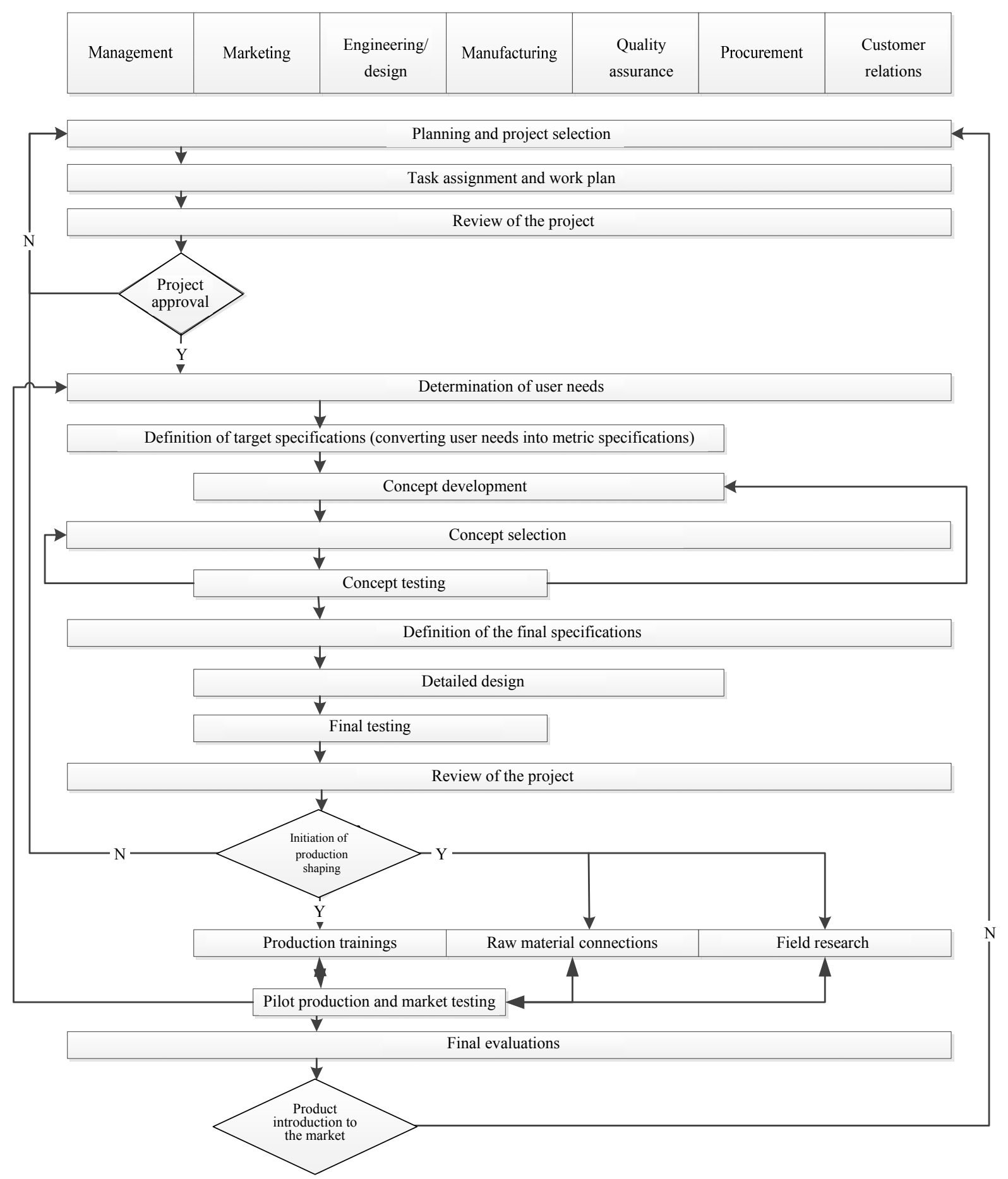

Fig. 1 Proposed NPD methodology for floor coverings.

procurement, and customer relations. It consists of the steps listed below:

- planning and project selection (identification of opportunities, evaluation and prioritization of projects, resource and time planning);
- task assignment and work plan;

- review of the project and project approval;

- determination of user needs;

- definition of target specifications;

- concept development; 
- concept selection;

- concept testing;

- definition of final specifications;

- detailed design;

- final testing;

- review of the project;

- initiation of product shaping;

- product trainings, raw material connections and field research;

- pilot production and market testing;

- final evaluations;

- product introduction to the market.

Three of the above listed steps, namely project approval, initiation of product shaping and introduction of the product to the market, are critical in which they are actually the control points in the project timeline.

\section{Applicability Evaluation of the Proposed NPD Process}

The applicability of the proposed methodology has been assessed by analyzing the respective processes of five of the leading companies engaged in the production of floor coverings in Turkey. To this end, first of all, their product development forms have been studied and summarized within the framework of the study. Then, a survey, which includes questions covering the activities in NPD, has been prepared and sent to these companies via e-mail. The survey is a mixture of open-end questions, multiple-choice questions and questions that the respondents have been asked to evaluate on a five point Likert scale. The first part of the survey is based on understanding if the steps of the proposed methodology are currently being realized in the NPD process of the companies. The second part consists of questions regarding the basic company information and organizational structure together with the general NPD process of the company. The rest of the survey seeks to understand in detail if and how the companies carry out the 17 steps of the proposed methodology.

\section{Results}

The analyses of the NPD processes, which have been summarized in Table 1 for four of the five companies, and the survey results for all the five companies subject to evaluation, reveal the following information:

- Four of the companies have listed in descending order of significance, the factors affecting their NPD decisions as "increasing market share", "holding onto present market share", and "getting into the market with an existing product but one that is new to the company";

- All of the five companies are engaged in both short-term and also long-term NPD plans. Two companies complete their new product projects in 3 to 6 months, the other two in 3 months to 1 year and one of them in a period as short as one month. This implies that most of the new products developed by these companies present a high level of innovation;

- All the companies have adopted a proactive NPD strategy, which means that they determine the user needs and design their new products accordingly, giving them the competitive advantage of being the first in the market. Thus, it can be stated that these companies are technologically innovative as well;

- When the characteristics of new product development activities are examined, it is seen that all of the companies have $R \& D$ (research and development) departments, i.e., the NPD activities are deemed significant in these companies;

- The payback period of new product investments is around 1 to 2 years in more than half of the companies and less than 1 year in the others. Shorter payback period of a new product indicates higher success in the market;

- In four of the five companies, management, finance, marketing and production departments are involved in the NPD process while all the companies include the R\&D departments and three of them also organize a cross-departmental project team in this process. Based on this information, it can be stated that 
Table 1 NPD processes of selected companies.

\begin{tabular}{|c|c|c|c|}
\hline Company A NPD process & Company B NPD process & Company C NPD process & Company D NPD process \\
\hline $\begin{array}{l}\text { (1) Demand notification } \\
\text { (2) Design and development } \\
\text { planning } \\
\text { (3) Laboratory testing } \\
\text { (4) Design cost calculation } \\
\text { (5) Outcome control } \\
\text { (6) Decision } \\
\text { (7) Review } \\
\text { (8) Information form } \\
\text { preparation for pilot production } \\
\text { (9) Product tree preparation for } \\
\text { pilot production } \\
\text { (10) Planning for pilot } \\
\text { production } \\
\text { (11) Manufacturability } \\
\text { verification (trial production) } \\
\text { (12) Review } \\
\text { (13) Development of product } \\
\text { tree } \\
\text { (14) Decision } \\
\text { (15) Verification of } \\
\text { compatibility with technical } \\
\text { specifications } \\
\text { (16) Decision } \\
\text { (17) Review } \\
\text { (18) Cost calculation } \\
\text { (19) Decision } \\
\text { (20) Introduction to the } \\
\text { production schedule }\end{array}$ & $\begin{array}{l}\text { (1) New product demand } \\
\text { (2) Preparation of design and } \\
\text { development plan } \\
\text { (3) Shared evaluation of the } \\
\text { respective administrative and } \\
\text { technical units } \\
\text { (4) Design input } \\
\text { identification } \\
\text { (5) Design output } \\
\text { establishment } \\
\text { (6) Design review and } \\
\text { validation } \\
\text { (7) Control and approval } \\
\text { (8) Recording of the results in } \\
\text { the design summary form } \\
\text { (9) Control and approval } \\
\text { (10) Introduction to the } \\
\text { production schedule }\end{array}$ & $\begin{array}{l}\text { (1) New product demand } \\
\text { (2) Design } \\
\text { (3) Capability evaluation of } \\
\text { the existing production line } \\
\text { and establishment of new } \\
\text { lines (if needed) } \\
\text { (4) Product dimension and } \\
\text { surface evaluation and } \\
\text { procurement of new casts (if } \\
\text { needed) } \\
\text { (5) Acquirement of } \\
\text { semi-products and materials } \\
\text { (if needed) } \\
\text { (6) Preparation for } \\
\text { laboratory sample product } \\
\text { (7) Sample production } \\
\text { (8) Check for conformance } \\
\text { to standards } \\
\text { (9) Customer approval } \\
\text { (10) Product pricing } \\
\text { (11) New product coding } \\
\text { and production line } \\
\text { preparation }\end{array}$ & $\begin{array}{l}\text { (1) New product demand } \\
\text { (2) Film preparation } \\
\text { (3) Application preparation } \\
\text { (4) Cast preparation } \\
\text { (5) Product prototypes } \\
\text { (6) Prototype approval } \\
\text { (7) Customer approval } \\
\text { (8) Preparation of production } \\
\text { files } \\
\text { (9) Submission of prototype } \\
\text { files and standards } \\
\text { (10) Planning and preparation } \\
\text { for production } \\
\text { (11) Product testing } \\
\text { (12) Introduction to the } \\
\text { production schedule }\end{array}$ \\
\hline
\end{tabular}

the most important criteria used in the evaluation of new products are the product's sales performance and the positive effect of the product on company image;

- All of the companies prefer to develop completely new products either by their own resources or by purchasing license and patents. Customer analysis is conducted in forming new product ideas. However, it is observed that none of the companies use customer complaints for new product ideas. Only two companies are taking users' feedbacks into consideration during the concept testing phase of the NPD process;

- Three of the companies are aware of the fact that detection and solution of the potential problems are much easier and less costly during product development as opposed to dealing with them in the latter stages. Hence, the review and evaluation stages of the NPD process are critical for the companies;

- All the companies place emphasis on determination of customer needs during NPD process;

- Four of the companies do not realize the whole set of activities required in definition of target specifications, which include forming a list of the metric properties, collecting competitive assessment information, identifying the ideal and minimum target values and integrating the gathered information into the process. There is only one company that carries out all of these activities. Thus, it can be stated that this stage of the NPD process is not taken seriously enough by most of the companies;

- Concept development step is realized in all the companies. One common operational problem identified during concept development is the fact that only a few alternatives are taken into consideration. This implies that a more democratic and efficient 
brainstorming environment should be built for idea generation and sharing;

- Only one of the companies has engaged itself in all the required activities during the development of final specifications. These activities consist of building a technical model of the product, establishing a cost model, simplifying the values attached with the product characteristics and making commercial substitutes where necessary, identifying the sub-categories under product characteristics and finally integrating the gathered information into the overall process. Thus, it can be stated that more emphasis should be placed on the development of final specifications;

- The activities deemed significant by the companies during detailed design are checking if the product has the expected level of quality/reliability, making the necessary preparations for initial production and planning when to introduce the product to the market. It can be observed that these issues are related to engineering, production and marketing departments;

- During the final testing stage, the companies mostly test the normative, production-specific and technical properties of their new products;

- In four companies, employees involved in production attend the related trainings;

- During final evaluation and introduction to the market, the most significant issue for the companies is the measurement of the product's market performance. This is followed by the assessment of product acknowledgement by the customers, realization of product enhancements, design review and evaluation of the suggestions for changes in the processes. Thus, it can be concluded that the companies try to understand how their products are perceived in the market and that they want to measure their products' performance in the face of competition;

- During the last stage of NPD, introduction to the market, all the companies subject to evaluation carry out the necessary activities involved in this process within the framework of a marketing plan.

\section{Conclusions}

An NPD process for floor coverings has been proposed and its applicability has been assessed through an in-depth analysis of the respective methods of the leading companies in the construction sector in Turkey. This assessment revealed that all the companies place emphasis on NPD in that the required personnel assignment has been realized and a systematic perspective is present. Moreover, they implement almost all the steps of the proposed methodology while developing new products. There are many commonalities in their NPD processes such as the fact that they are all initiated with new product demand and finalized with product introduction to the market. However, there are certain differences as well depending on the company profile. Two stages of the NPD methodology, namely definition of target and final specifications, require more attention and effort in which the gathered information should be integrated into the overall process to enhance the success of new products. All the companies place emphasis on customer needs and expectations in their NPD processes. On the other hand, taking into consideration the users' feedbacks during the concept testing stage and investigating the customer complaints more thoroughly for new product ideas could provide them competitive advantage in the dynamic business environment. In conclusion, the proposed methodology is believed to reflect a holistic perspective for NPD and the companies whose processes have been reviewed can effectively integrate it into their operations with minor adjustments. Nevertheless, it can be enhanced by thoroughly considering the three aspects of sustainability, namely environmental, economic, and social. Especially, the social issues regarding sustainability such as corporate social responsibility require more attention in the academic arena. Moreover, the integration of suppliers and customers 
as business partners in NPD and the management of the associated risks together with the effects of the organizational aspects (i.e., management support and organizational learning) are also possible areas of future research in this field.

\section{References}

[1] Menon, A., Chowdhury, J., and Lukas, B. 2002. "Antecedents and Outcomes of New Product Development Speed: An Interdisciplinary Conceptual Framework." Industrial Marketing Management 31 (4): 317-28.

[2] Thomas, E. 2013. "Supplier Integration in New Product Development: Computer Mediated Communication, Knowledge Exchange and Buyer Performance." Industrial Marketing Management 42 (6): 890-9.

[3] Chwastyk, P., and Kolosowski, M. 2014. "Estimating the Cost of the New Product in Development Process." Procedia Engineering 69: 351-60.

[4] Jafarian, M., and Bashiri, M. 2014. "Supply Chain Dynamic Configuration as a Result of New Product Development." Applied Mathematical Modelling 38 (3): 1133-46.

[5] Leber, M., Bastič, M., Mavrič, M., and Ivanišević, A. 2014. "Value Analysis as an Integral Part of New Product Development." Procedia Engineering 69: 90-8.

[6] Tracey, M., and Neuhaus, R. 2013. "Purchasing's Role in Global New Product-Process Development Projects." Journal of Purchasing and Supply Management 19 (2): 98-105.

[7] Wang, J., and Lin, Y. I. 2009. “An Overlapping Process Model to Assess Schedule Risk for New Product Development." Computers \& Industrial Engineering 57 (2): 460-74.

[8] Song, W., Ming, X., and Xu, Z. 2013. "Risk Evaluation of Customer Integration in New Product Development under Uncertainty." Computers and Industrial Engineering 65 (3): 402-12.
[9] Gmelin, H., and Seuring, S. 2014. "Determinants of a Sustainable New Product Development." Journal of Cleaner Production 69: 1-9.

[10] Felekoglu, B., Maier, A. M., and Moultrie, J. 2013. "Interactions in New Product Development: How the Nature of the NPD Process Influences Interaction between Teams and Management." Journal of Engineering and Technology Management 30 (4): 384-401.

[11] Gmelin, H., and Seuring, S. 2014. "Achieving Sustainable New Product Development by Integrating Product Life-Cycle Management Capabilities." International Journal of Production Economics 154 (August): 166-77.

[12] Campbell, J. L. 2007. "Why Would Corporations Behave in Socially Responsible Ways? An Institutional Theory of Corporate Social Responsibility." Academy of Management Review 32 (3): 946-67.

[13] Oehmen, J., Ben-Daya, M., Seering, M., and Al-Salamah, M. 2007. "Risk Management in Product Design: Current State, Conceptual Model and Future Research." In Proceedings of the 36th Design Automation Conference, Parts $A$ and B, 1033-41.

[14] Oehmen, J., Olechowski, A., Kenley, C. R., and Ben-Daya, M. 2014. "Analysis of the Effect of Risk Management Practices on the Performance of the New Product Development Programs." Technovation 34 (8): 441-53.

[15] McGrath, M. E. 1996. Setting the Pace in Product Development: A Guide to Product and Cycle-Time Excellence. Boston: Butterworth-Heinemann Ltd.

[16] Ulrich, K. T., and Eppinger, S. D. 2004. Product Design and Development. 3rd ed.. New York: McGraw-Hill.

[17] Perreault, W. D., and McCarthy, E. J. 1996. Basic Marketing: A Global Managerial Approach. 12th ed.. Chicago: Irwin.

[18] Etzel, M. J., Walker, B. J., and Stanton, W. J., 2001. Marketing. 12th ed.. Boston: McGraw-Hill.

[19] Kotler, P., and Armstrong, G. 2000. Marketing: An Introduction. 5th ed.. New Jersey: Prentice Hall Inc. 